\title{
Conference Report: Arabic Computing Seminar
}

\author{
ANDREW RIPPIN
}

$\mathrm{O}^{n}$

N September 6 and 7, 1989, the Seminar on Bilingual Computing in Arabic and English was held at the University of Cambridge, jointly organized by The Literary and Linguistic Computing Centre and The Centre for Middle Eastern Studies. ${ }^{1}$ Over twenty-five papers were presented and about one hundred people were in attendance; many of the attendees were from the Arab world. The seminar provided the opportunity to hear about the state of the art in Arabic computing, its problems and prospects.

From my own perspective, two themes seemed to dominate much of the proceedings. The first theme related to the development of large databases of Arabic language material and the uses to which these could be put. This is an area in which commercial concerns are tapping the field for its possibilities, as several presentations made very clear. The paper by $\mathrm{Dr}$. $\mathrm{T}$. Moller of Litton Industries, "Arab World On-Line, a Bilingual Information Utility," outlined a proposal which had been put forward to (but not yet implemented by) the Kuwait Foundation for the Advancement of Science for an on-line database of information about the Arab world. The system is planned to be bilingual, Arabic and English, and the material which is going to be made available will be to a large extent current technical and government documents. While the desire is to have as much information on-line as possible, in many cases only manually keyed-in abstracts are going to be immediately available along with graphic images of selected items. The on-line database will be combined with the use of FAX in order to deliver the full version of any citation found listed there. The reason for this lies primarily with the inability of present optical character recognition technology to deal with the complexities of Arabic; thus there is no efficient way to enter a very large amount of Arabic data into the computer database. This situation may well change in time.

Similarly, Ubaidly Ubaidly of Al-Fihrist, Cyprus, spoke on the "Construction of an Arabic-based Multilingual Thesaurus for Indexing," which related to methods of searching a database of political, military, economic, and development issues being undertaken by the Institute for Middle Eastern Studies, Beirut. The information in the database comes from

1 Ed. note: See the section "Conferences" below for the full list of papers and authors. 
twenty-five weekly magazines and almost two hundred periodicals, all in Arabic. At the present moment, this material cannot be accessed on-line, but future plans aim towards this goal.

These sorts of databases may be thought to have limited relevance to most scholars; however, the potential which these and similar systems manifest may ultimately provide a significant resource for academic work. Such databases will provide a body of readily available material for linguistic analysis, dictionary compilation, and language teaching. This was a need that emerged in several other sessions in the seminar.

Three papers on lexicography, all by scholars from Kuwait, dealt with issues related to dictionary compilation, especially regarding how much information should be included in such dictionaries and how they should be structured (e.g., whether vowels should be included, whether words should be entered alphabetically or by root). Dr. Robin Thelwall and Dr. Mohamed Sami Anwar both dealt with issues relating to the terminology and the linguistic framework through which computerized dictionaries should be compiled, issues which need to be faced in order to take advantage of the power and abilities of computer-based technology. Dr. Mohamad Farhat spoke of the desirability of constantly updating the database from which dictionaries are compiled and precisely how computers facilitate such aspects - as long as the databases themselves are available by which this may take place.

Similar observations were made in three papers relating to machine translation and syntactical analysis of Arabic-projects being worked upon in both Egypt and the United States-but it was especially papers on teaching Arabic via computer that pointed to the need for computer readable material.

In general, teaching Arabic via computer would appear to be making steps forward, but only very slowly and with limited input, unfortunately, from teachers experienced in computer assisted instruction (CAI) systems and programmers experienced in writing such programs. Much of the material-as described and displayed by a team from the University of Leeds and by Dilworth Parkinson from Brigham Young University-is still rudimentary in terms of the ideals of CAI. This situation may not be of great concern for instructors dealing with motivated students who simply wish to facilitate the learning process via computer-based drills; they may well tolerate a certain level of drudgery and inanity. For other students, however, flash card systems and unconnected prose pieces do little. The goal, therefore, of the latest developments from the University of Leeds, as discussed by Dr. Adrian Brockett and M. Page, to create or gain access to a vast database of texts-even commercial ones-which may then be utilized in a teaching situation, may well lead to an improvement in the materials available in the future. Students will be confronted by real Arabic passages on a subject matter which they can choose according to their interests. 
But what of the vast storehouse of classical Arabic texts which could be employed in areas of lexicography, translation, and teaching? According to the organizers of the seminar, although papers were solicited under the rubric "Islamic Studies," none were received. It is therefore not easy to judge where that discipline stands on creating machine-readable texts which could be subjected to further computer-based analysis and employment. Whether this absence of response really indicates that those in traditional fields of Islamic studies are using their computers only for word-processing and little else is unclear, but it appears that, unfortunately, it may be true. For example, as far as I am aware, there is still not a plain ASCII text (i.e., in an unencrypted format) of the Qur'ān available for scholarly use. Likewise for hadith material, Both corpora exist in commercial form (very impressive demonstrations were given at the seminar by the Kuwaiti company al-Alamiah of their sophisticated Qur'ān and hadith databases) but all keep the texts in encrypted code. Overall, the number of classical Arabic texts in electronic form which are readily available for general use would seem to be excruciatingly small. This is an area of tremendous potential for the future but, as far as this seminar was concerned, no one seemed willing or able to talk of their projects or even plans in this regard.

The other theme which emerged out of the seminar and which generated a good deal of discussion was the need for communication among scholars and teachers in the field. There seems to be a good deal of duplication of effort between various universities, and it is frequently difficult to know just what is being planned and implemented throughout the world with regards to Arabic and computers. Everhard Ditters of the University of Nijmegen drew attention to his journal Processing Arabic (now in its fourth issue) as a good forum for communications and dissemination of news. For information, Everhard may be contacted at: TCMO - Nijmegen University, P.O. Box 9103, 6500 HD Nijmegen, Netherlands, or via electronic mail: U279300@HNYK@JN11.

Good news in terms of ongoing communication and discussion was also presented in the form of the announcement of next year's seminar at Cambridge, which is already in the planning stages. Themes being pursued are: software copy protection problems in the Arab world, bilingual databases (compiling classical Arabic sources and contemporary data banks), and media on bilingual computing (magazines, books, and manuals). Papers are invited on these subjects. Contact should be made as soon as possible with: Ahmad Ubaydli, c/o Literary and Linguistic Computing, Sidgwick Avenue, Cambridge CB3 9DA, England, or via electronic mail: AU100 @UNCAMULT.BITNET.

University of Calgary 


\section{New Views on the Middle East}

\section{Palestine and Israel}

The Uprising and Beyond DAVID McDOWALL

"The book is a masterpiece: by far the most penetrating and comprehensive analysis of the Palestine problem that I have read. ... If any book can contribute to clearer discussion of this tragic and intractable issue, at a time when it is definitely back on the international agenda, this is surely it."

-Edward Mortimer, Foreign Affairs Editor, The Financial Times $\$ 24.95$

\section{Lives at Risk}

\section{Public Health in}

Nineteenth-Century Egypt

LaVERNE KUHNKE

"Should be read by all scholars and students of modern Egyptian history as well as of the problems of disease and health in developing countries."

-Arthur E. Goldschmidt,

Pennsylvania State University

Comparative Studies of Health

Systems and Medical Care $\$ 40.00$

\section{The Art and}

\section{Architecture of the Islamic World \\ KATHARINA OTTO-DORN}

"One of the best surveys of the whole field of Islamic art and architecture in any language, it is particularly strong for early and medieval Islam."

-Anthony Welch, Dean, Faculty of Fine Arts, University of Victoria $\$ 65.00$

\section{Asad of Syria}

The Struggle for the Middle East PATRICK SEALE

Now in paper-"This is a book in the finest tradition of investigative scholarship. The research is awesome. . . Seale's great strength is his ability to explain the confusing kaleidoscopic nature of Middle Eastern diplomacy. He understands the game being played and also knows the players."

- Los Angeles Times Book Review $\$ 12.95$ paper

\section{Truman and Israel MICHAEL J. COHEN}

"An excellent, provocative, and major book."

-William Roger Louis,

University of Texas and

St. Anthony's College, Oxford

"This volume will become the best known and most respected book on the subject of Truman and the Zionist quest."

-Steven L. Spiegel, UCLA $\$ 24.95$

\section{The Poetics of Military Occupation} Mzeina Allegories of Bedouin Identity Under Israeli and Egyptian Rule SMADAR LAVIE

Using theories from post-modernist literary criticism and from performance studies, anthropolgist Lavie shows how the South Sinai Mzeina have adapted to constant military rule. $\$ 29.95$

\section{Islam, Politics, and Social Movements} Edited by EDMUND BURKE, III, and IRA $M$. LAPIDUS

Now in paper-"Most books inspired by the Iranian revolution and the political resurgence of Islam are concerned with immediate events, and many focus narrowly on the core states of the Middle East. The 13 case studies in this volume collectively cover a much broader historical and geographic range."-Choice Comparative Studies on Muslim Societies $\$ 11.95$ paper

At bookstores or order toll-free 1-800-822-6657. Visa \& MasterCard only.

\section{University of California Press}

Berkeley 94720 